\title{
OXIDATION OF CYCLOHEXANOL ON PHOSPHOTUNGSTIC ACID ANION INTERCALATED LAYERED DOUBLE HYDROXIDES WITH AQUEOUS $\mathrm{H}_{2} \mathrm{O}_{2}$ AS OXIDANT
}

\author{
Xueli Bai ${ }^{a}$, Zhaoyang Bai ${ }^{\mathrm{b}}$, Dandan Xue ${ }^{\mathrm{a}}$, Huiyan Sun ${ }^{\mathrm{a}}$, Xin Huanga , Yongxiang Zhao ${ }^{\mathrm{a}, \mathrm{t}}$ and Yue Zhang,* \\ ${ }^{a}$ Engineering Research Center of Ministry of Education for Fine Chemicals, School of Chemical Engineering, Shanxi University, \\ Taiyuan 030006, Shanxi, China \\ ${ }^{b}$ Department of Animal Medicine, College of Animal Science and Technology, Shanxi Agricultural University, Taigu 030801, \\ Shanxi, China
}

Recebido em 03/06/2017; aceito em 04/09/2017; publicado na web em 27/10/2017

\begin{abstract}
The layered double hydroxides ( $\mathrm{LDH}$ ) of $\mathrm{Mg}_{2} \mathrm{AlNi}$ and $\mathrm{Mg}_{3} \mathrm{Al}$ pillared by Keggin-type phosphotungstic acid anion (POM), i.e. $\mathrm{Mg}_{2} \mathrm{AlNi}-\mathrm{POM} \mathrm{LDH}$ and $\mathrm{Mg}_{3} \mathrm{Al}-\mathrm{POM} \mathrm{LDH}$ were synthesized by an ion-exchange method. The synthesized POM intercalated LDH compounds were characterized using various techniques such as FTIR, XRD, TGA and BET. The observed results show that the obtained catalysts retain the layer structure of $\mathrm{LDH}$. Compared with the binary $\mathrm{Mg}_{3} \mathrm{Al}-\mathrm{POM} \mathrm{LDH}$, the ternary $\mathrm{Mg}_{2} \mathrm{AlNi}-\mathrm{POM} \mathrm{LDH}$ catalyst indicated a higher thermal and chemical stability. The catalytic activity of the resulting LDH-POM was also assessed in the green oxidation of cyclohexanol with aqueous $\mathrm{H}_{2} \mathrm{O}_{2}$ as an oxidant. The $\mathrm{Mg}_{2} \mathrm{AlNi}-\mathrm{POM}$ LDH showed a much higher conversion and selectivity for cyclohexanone than the corresponding $\mathrm{Mg}_{3} \mathrm{Al}-\mathrm{POM} \mathrm{LDH}$ catalyst.
\end{abstract}

Keywords: layered double hydroxides; heterogeneous catalysis; phosphotungstic acid; ion-exchange; oxidation.

\section{INTRODUCTION}

It is well known that the carbonyl compounds have widespread applications in dyestuff, perfumery and agro chemical industries. ${ }^{1-3}$ Oxidation of alcohols has traditionally been the major route for the preparation of carbonyl compounds. However, many of the traditional inorganic oxidants utilized for the oxidation of alcohols are hazardous or toxic, for example $\mathrm{Na}_{2} \mathrm{Cr}_{2} \mathrm{O}_{7}, \mathrm{NaClO}_{4}$ and $\mathrm{KMnO}_{4}$. Therefore, it is necessary to find green and clean catalysts and oxidants for the oxidation of alcohols.

One ideal oxidant for the oxidation of alcohols is hydrogen peroxide as it can oxidize the organic compounds with the formation of water as a by-product. ${ }^{4,5}$ Noyori reported various polyoxometalate (POM) catalysts in the oxidation of organic compounds with aqueous $\mathrm{H}_{2} \mathrm{O}_{2}$ as the oxidant. (POMs) ${ }^{6-9}$ have widely been used in the catalytic oxidation reaction due to their oxidative stability and high efficiency. ${ }^{10-12}$ The homogeneous catalysis is green, highly efficient and environmentally pollution-free, ${ }^{13,14}$ but there are inherent problems existing with this method such as the difficult separation of the product and thus the catalyst is easily lost in the process. Hence, it is absolutely necessary to heterogenize the soluble POMs.

In this context, one potential strategy could be by using the layered double hydroxides (LDHs), which are the type of anionic clay materials with layered structure. The layers as a result carry positive charges that are balanced by the interlayer anions ${ }^{15}$ which could be replaced by various POM anions through ion-exchange. ${ }^{15-20}$ This provids an effective route for heterogenizing the catalysts in a homogeneous medium. Besides, these POM-pillared LDH (POM/ $\mathrm{LDH})$ materials were tested for the oxidation of benzaldehyde, ${ }^{21}$ cyclohexene ${ }^{22}$ and allyl alcohol ${ }^{23}$ with aqueous $\mathrm{H}_{2} \mathrm{O}_{2}$ in the absence of an organic solvent. The observed results indicate that LDH precursors can effectively influence the conversion and selectivity in the catalytic reaction.
In addition, POM/LDH showed a high recovery rate and good thermal stability ${ }^{24}$ in the catalytic process. The diversity of POM/ $\mathrm{LDH}$ is due to the adjustable oxyacid of POM as well as adjustable distribution of the metal cations on the surface of LDH layers, which lead to a difference in the structure and catalytic performance. To date, the studies related to POM/LDH mainly focusing on changing the composition of POMs, and their $\mathrm{LDH}$ precursors largely utilizing binary $\mathrm{Mg} / \mathrm{Al}-\mathrm{LDH}$ or $\mathrm{Zn} / \mathrm{Al}-\mathrm{LDH}$ (for instance, $\mathrm{Mg}_{2} \mathrm{Al}-\mathrm{W}_{7} \mathrm{O}_{24}{ }^{6-}$ $\mathrm{LDHs},{ }^{25} \mathrm{Zn}_{2} \mathrm{Al}-\left[\mathrm{SiW}_{11} \mathrm{O}_{39}\right]_{0.12} \cdot 0.2 \mathrm{H}_{2} \mathrm{OLDH}^{15}$ and $\mathrm{ZnAl}-\left[\mathrm{EuW}_{10} \mathrm{O}_{36}\right]^{9-}$ $\left[\mathrm{Eu}\left(\mathrm{BW}_{11} \mathrm{O}_{39}\right)\left(\mathrm{H}_{2} \mathrm{O}\right)_{3}\right]^{6-/} /\left[\mathrm{Eu}\left(\mathrm{PW}_{11} \mathrm{O}_{39}\right)_{2}\right]^{11-} \mathrm{LDH}^{26}$ etc. $)$. However, the $\mathrm{Mg} / \mathrm{Al}-\mathrm{LDH}$ precursor easily causes a severe acid-base reaction with the POM solution. ${ }^{23-27}$ The reaction can be controlled through changing the composition of LDH precursor.

In recent years, non-precious metals such as $\mathrm{Ni},{ }^{28,29} \mathrm{~V}^{30}$ and $\mathrm{Cu}^{31,32}$ have been successfully used as heterogeneous catalysts in modifying the inorganic matrices as for the oxidation of alcohols. Nickel is usually applied as an active species for the reduction reaction. In the current work, we reduced the basicity of LDH precursor by adding nickel to the binary $\mathrm{Mg} / \mathrm{Al}-\mathrm{LDH}$, as the basicity of nickel is weaker than magnesium. The ternary catalyst has good stability. Moreover, it is well known that nickel is usually applied as an active species in the heterogeneous catalysis for the oxidation of alcohol. ${ }^{28,29}$ Therefore, the performance could be improved in the oxidation of cyclohexanol with aqueous $\mathrm{H}_{2} \mathrm{O}_{2}$ as an oxidant by adding a metal nickel to the binary $\mathrm{Mg} / \mathrm{Al}-\mathrm{LDH}$. We hereby reported the preparation and characterization of ternary $\mathrm{Mg}_{2} \mathrm{AlNi}$-POM LDH catalyst using 12-phosphotungstic acid anions ([PW $\left.{ }_{12} \mathrm{O}_{40}\right]^{3-}$, referred to as "POM") which are intercalated between the $\mathrm{LDH}$ layers replacing the nitrate anions via ion-exchange pathway. Also, the structure of $\mathrm{Mg}_{2} \mathrm{AlNi}$-POM LDH and its catalytic performance in the oxidation of cyclohexanol have been compared with the $\mathrm{Mg}_{3} \mathrm{Al}-\mathrm{POM} \mathrm{LDH}$ catalyst. As the precursor, the ternary $\mathrm{Mg}_{2} \mathrm{AlNi}-\mathrm{LDH}$ not only improves the stability of POM-LDH catalyst but also enhances the selectivity for the oxidation of cyclohexanol under mild conditions and in presence of water as solvent. 


\section{EXPERIMENTAL}

\section{Materials and methods}

$\mathrm{Mg}\left(\mathrm{NO}_{3}\right)_{2} \cdot 6 \mathrm{H}_{2} \mathrm{O}(\mathrm{AR}), \mathrm{Al}\left(\mathrm{NO}_{3}\right)_{3} \cdot 9 \mathrm{H}_{2} \mathrm{O}(\mathrm{AR})$ and $\mathrm{Ni}\left(\mathrm{NO}_{3}\right)_{2} \cdot 6 \mathrm{H}_{2} \mathrm{O}$ (AR) were purchased from the Tianjin Hengxing Chemical manufacturing co., LTD. $\mathrm{Na}_{3}\left[\mathrm{PW}_{12} \mathrm{O}_{40}\right]$ (AR) and cyclohexanol (AR) were purchased from Sinopharm Chemical manufacturing co., LTD. Aqueous $\mathrm{H}_{2} \mathrm{O}_{2}$ (30 wt\%; AR) was purchased from Beijing chemical factory.

$\mathrm{X}$-ray diffraction (XRD) patterns were recorded on a German Bruker D8 Advance X-ray powder diffraction system $\left(\mathrm{CuK}_{\alpha}, 40 \mathrm{kV}\right.$, $40 \mathrm{~mA}$ ). FT-IR spectra were collected on a Bruker Tensor 27 infrared spectrometer, using the $\mathrm{KBr}$ pallet method. TEM micrographs were taken using Japanese Jeol TEM-2100 type transmission electron microscopy. Gas chromatography(GC) were used Agilent Technologies GC-7890B type chromatograph, $\mathrm{N}_{2}$ as carrier gas. The nitrogen sorption experiments were performed at $196^{\circ} \mathrm{C}$ on an ASAP 2020 system. TGA/ DTA analysis using STA449F3 type comprehensive thermal analyzer was produced of Germany NETZSCH, the heating rate of $10^{\circ} \mathrm{C} / \mathrm{min}$. The crucible material is alumina. The gas is a mixture of nitrogen and oxygen and their rate is $5 \mathrm{~mL} / \mathrm{min}$ and $20 \mathrm{~mL} / \mathrm{min}$ respectively.

\section{Preparation of catalyst precursors and LDH-POM catalysts}

A solution containing $30 \mathrm{mmol}$ of $\mathrm{Mg}\left(\mathrm{NO}_{3}\right)_{2} \cdot 6 \mathrm{H}_{2} \mathrm{O}$ and $10 \mathrm{mmol}$ of $\mathrm{Al}\left(\mathrm{NO}_{3}\right)_{3} \cdot 9 \mathrm{H}_{2} \mathrm{O}$ in $100 \mathrm{~mL}$ of decarbonated water and an aqueous solution of $1 \mathrm{~mol} / \mathrm{L} \mathrm{NaOH}$ were simultaneously added dropwise to a $250 \mathrm{~mL}$ three-necked flask having (with $50 \mathrm{~mL}$ of deionized water) which was under with rapid stirring and under nitrogen atmosphere. The relative rates of adding the mixed solution of nitrate salts and the $1 \mathrm{~mol} / \mathrm{L}$ of $\mathrm{NaOH}$ solution were adjusted to maintain the $\mathrm{pH} \approx 10$. The resulting suspension was kept at $80{ }^{\circ} \mathrm{C}$ for $12 \mathrm{~h}$ in the hydrothermal synthesis reactor. Then, the slurry was separated into two equal portions. One portion was centrifuged and washed with water for several times (until $\mathrm{pH} \approx 7$ ), and the resulting precipitate was dried at $120^{\circ} \mathrm{C}$ overnight to obtain $\mathrm{Mg}_{3} \mathrm{Al}-\mathrm{NO}_{3} \mathrm{LDH}$ which was used for further characterization.

After centrifugation and washing, the other portion of the precipitate was dispersed in $100 \mathrm{~mL}$ water and maintained under $\mathrm{N}_{2}$ as $\mathrm{Mg}_{3} \mathrm{Al}-\mathrm{NO}_{3} \mathrm{LDH}$ slurry which was simultaneously added dropwise with POM (10 mmol) to a $250 \mathrm{~mL}$ three-necked flask. The mixed slurry was stirred for $3 \mathrm{~h}$ at $60^{\circ} \mathrm{C}$. The $\mathrm{pH}$ of the dispersion was around 4.8, which is suitable for the POM anion as the $\left[\mathrm{PW}_{12} \mathrm{O}_{40}\right]^{3-}$ is stable in the $\mathrm{pH}$ range of $2-6 .{ }^{33}$ Finally, $\mathrm{Mg}_{3} \mathrm{Al}-\mathrm{POM} \mathrm{LDH}$ catalyst was obtained. The synthesis of $\mathrm{Mg}_{2} \mathrm{AlNi}-\mathrm{NO}_{3} \mathrm{LDH}$ and $\mathrm{Mg}_{2} \mathrm{AlNi}-\mathrm{POM}$ LDH slurry is similar to $\mathrm{Mg}_{3} \mathrm{Al}-\mathrm{NO}_{3} \mathrm{LDH}$ and $\mathrm{Mg}_{3} \mathrm{Al}-\mathrm{POM} \mathrm{LDH}$ analogue which were obtained using $\mathrm{Mg}\left(\mathrm{NO}_{3}\right)_{6} \cdot 6 \mathrm{H}_{2} \mathrm{O}$ (20mmol), $\mathrm{Al}\left(\mathrm{NO}_{3}\right)_{3} \cdot 9 \mathrm{H}_{2} \mathrm{O}(10 \mathrm{mmol})$ and $\mathrm{Ni}\left(\mathrm{NO}_{3}\right)_{2} \cdot 6 \mathrm{H}_{2} \mathrm{O}(10 \mathrm{mmol})$.

In addition, we prepared a series of POM intercalated materials i.e. $\mathrm{Mg} / \mathrm{Al} / \mathrm{Ni}-\mathrm{POM} \mathrm{LDH}$ using the same method as above. The molar ratio of the $\mathrm{LDH}$ material i.e. $\mathrm{Mg}+\mathrm{Ni} / \mathrm{Al}$ is of $3: 1$ and the molar ratio of POM ( $1.43 \mathrm{mmol}, 1.43 \times 7 \approx 10 \mathrm{mmol})$ to the exchange negative charge capacity $(10 \mathrm{mmol})$ of LDH is $1: 7$.

\section{Oxidation of cyclohexanol}

In a typical experiment, a mixture of cyclohexanol (10 mmol), ethanol $(100 \mathrm{mmol})$, aqueous $\mathrm{H}_{2} \mathrm{O}_{2}(30 \%, 5 \mathrm{mmol})$ and $0.2 \mathrm{~g}$ of catalyst were refluxed at $90{ }^{\circ} \mathrm{C}$ for $2 \mathrm{~h}$. The resulted mixture was then cooled and toluene (10 mmol, internal standard) was added to the liquid phase and was then analyzed by GC to determine the conversion and selectivity. After being washed with ethanol and dried under vacuum, the recovered catalyst could be reused.

\section{RESULTS AND DISCUSSION}

\section{Synthesis and characterization of LDH-POM catalysts}

LDH-POM catalysts were synthesized through a synthetic route where POM anion could be directly inserted into LDH layers without adjusting the $\mathrm{pH}$.

XRD patterns of the as-prepared samples have been represented in Figure 1, and the major d(003) spacings (calculated using Bragg's equation, $\lambda=2 \mathrm{~d} \sin \theta$, where $\lambda=0.15406 \mathrm{~nm}$ ) are given in Table 1 . $\mathrm{Mg}_{2} \mathrm{AlNi}-\mathrm{POM} \mathrm{LDH}$ and $\mathrm{Mg}_{3} \mathrm{Al}-\mathrm{POM} \mathrm{LDH}$ have lower diffraction intensity of peaks compared with $\mathrm{Mg}_{2} \mathrm{AlNi}-\mathrm{NO}_{3} \mathrm{LDH}$ and $\mathrm{Mg}_{2} \mathrm{AlNi}-\mathrm{NO}_{3} \mathrm{LDH}$. Figure 1 shows that the peak position of $\mathrm{POM} / \mathrm{LDH}$ moves to lower 2-theta-diffraction angle, owing to the intercalation of POM anion intercalated into LDH. Furthermore, the major d(003) spacings of $\mathrm{Mg}_{2} \mathrm{AlNi}-\mathrm{POM} \mathrm{LDH}$ and $\mathrm{Mg}_{3} \mathrm{Al}-\mathrm{POM}$ LDH demonstrate a higher value. The d(003) spacing of LDH-POM includes the thickness of LDH host and the gallery height of interlayer region. Subtracting the thickness of host layer which is assumed to be about $0.48 \mathrm{~nm}$ gives the gallery heights of the LDH-POM to be about $0.98 \sim 1.01 \mathrm{~nm}$. The observed gallery heights are in agreement with the diameter of the short axis of POM anions $(\sim 0.98 \mathrm{~nm}) .^{33}$ The major diffraction peak and a low intensity peak, is indicated as (003). This mixture includes POM-intercalated LDH and the POM-immobilized LDH (POM anions immobilized on the external surface of LDH layers). Besides, the diffraction peak (110) is detected in all the samples which indicates that the layered structure of LDH is retained after immobilization. The intensity of the diffraction peak of (110) plane of POM-LDH is low, especially the $\mathrm{Mg}_{3} \mathrm{Al}-\mathrm{POM} \mathrm{LDH}$, which may be due to acid-base reaction that occurs between the acidic POM solution and the basic $\mathrm{Mg}_{3} \mathrm{Al}-\mathrm{NO}_{3}$ resulting in a partial decomposition of $\mathrm{LDH}$ host.

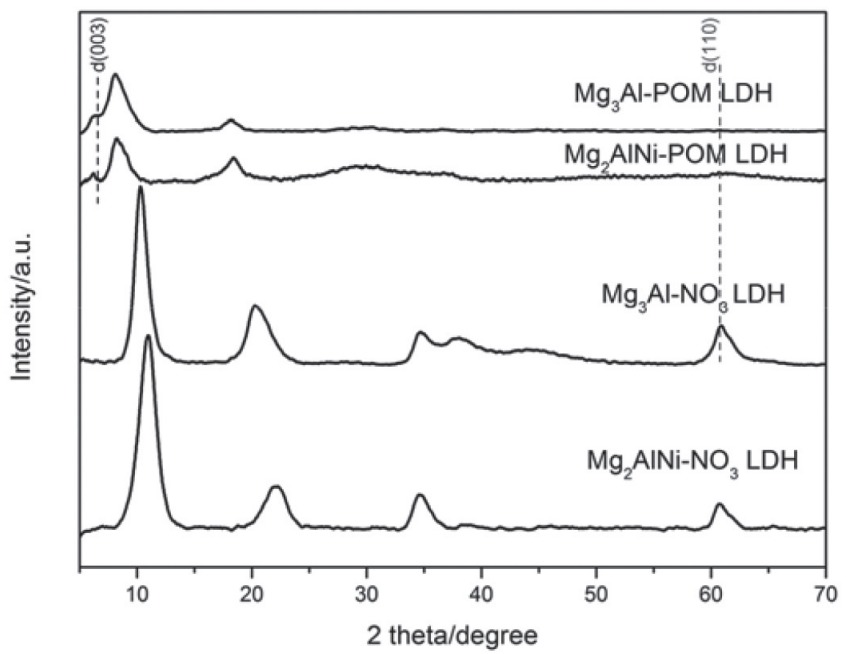

Figure 1. XRD patterns of different $\mathrm{LDH}-\mathrm{NO}_{3}$ supports and $\mathrm{LDH}-\mathrm{POM}$ catalysts

These results suggest that the POM anion has been successfully incorporate into the interlayer of LDH by the anion-exchange process.

The FT-IR spectra of the samples are shown in Figure 2. After intercalation, $\mathrm{Mg}_{2} \mathrm{AlNi}-\mathrm{POM} \mathrm{LDH}$ and $\mathrm{Mg}_{3} \mathrm{Al}-\mathrm{POM} \mathrm{LDH}$ showed the characteristic peaks at 812 and $742 \mathrm{~cm}^{-1}$, which are related to the $\mathrm{W}-\mathrm{O}_{\mathrm{c}}-\mathrm{W}$ and $\mathrm{W}-\mathrm{O}_{\mathrm{e}}-\mathrm{W}$ (c, corner; e, edge sharing) vibrations. The bands at 958 and $902 \mathrm{~cm}^{-1}$ are attributed to the vibration of $\mathrm{W}-\mathrm{O}_{\mathrm{t}}(\mathrm{t}$, terminal), and the peaks at 1083 and $1058 \mathrm{~cm}^{-1}$ are attributed to that of P-O. The $\mathrm{Mg}_{2} \mathrm{AlNi}-\mathrm{NO}_{3} \mathrm{LDH}$ and $\mathrm{Mg}_{2} \mathrm{AlNi}-\mathrm{NO}_{3} \mathrm{LDH}$ show a strong peak at $1384 \mathrm{~cm}^{-1}$ due to the vibration of $\mathrm{N}-\mathrm{O}$ from nitrate anion in the interlayer region. ${ }^{33}$ However, a weak peak of N-O still appeared 
from $\mathrm{Mg}_{2} \mathrm{AlNi}-\mathrm{POM} \mathrm{LDH}$ and $\mathrm{Mg}_{3} \mathrm{Al}-\mathrm{POM} \mathrm{LDH}$. These results suggest that the POM anions were exchanged into $\mathrm{LDH}$ which is in agreement with the results obtained from XRD patterns. However, based on the band appearing at $1384 \mathrm{~cm}^{-1}$ and the band at $1365 \mathrm{~cm}^{-1}$ which are attributed to the $\mathrm{C}-\mathrm{O}$ bonds, suggesting that the nitrate and the carbonate anions are incorporated between the layers of LDH. It illustrates that the anion exchange reaction is not completed and some of the nitrate anions remained partly and some samples are contaminated with carbonate anion.

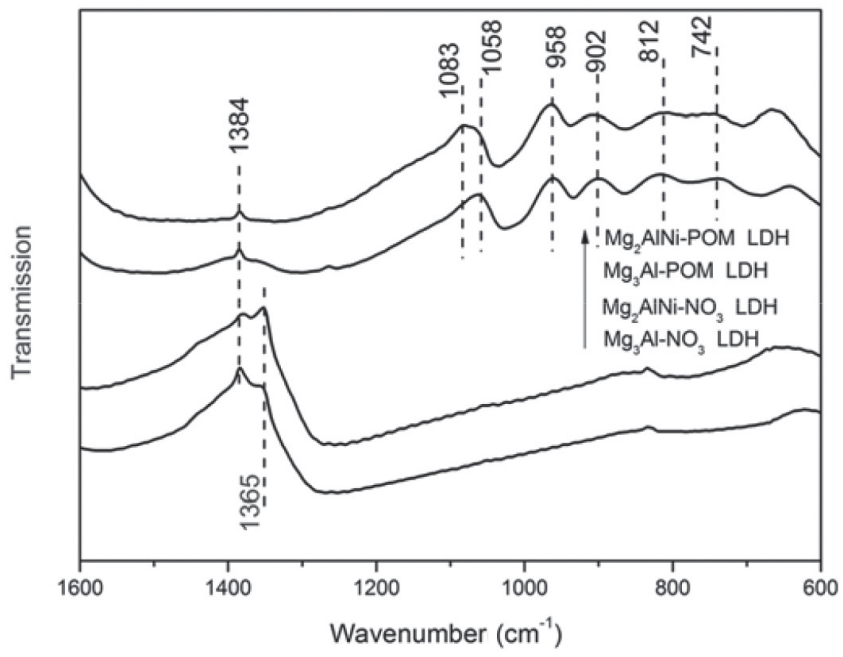

Figure 2. FT-IR spectra of different $\mathrm{LDH}-\mathrm{NO}_{3}$ and $\mathrm{LDH}-\mathrm{POM}$ samples

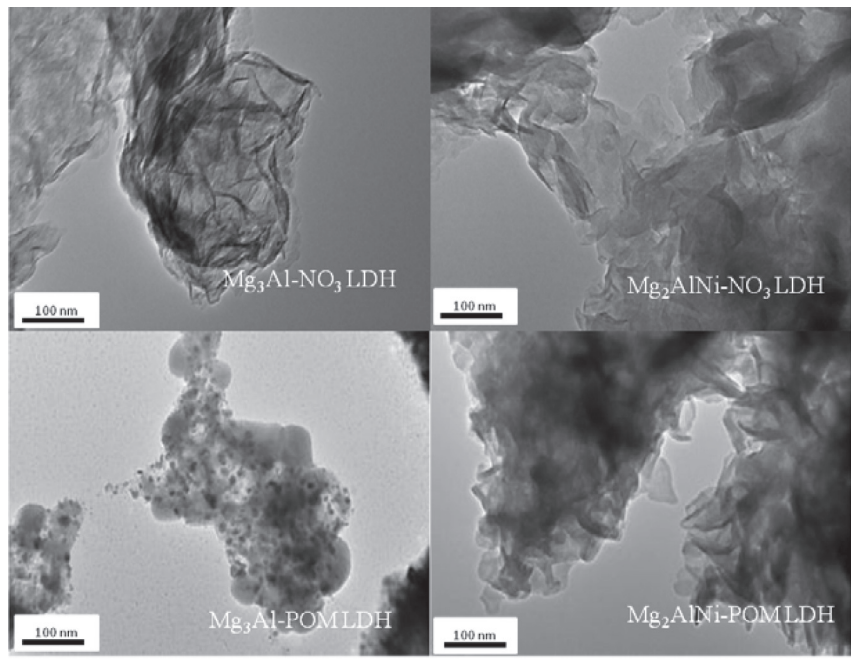

Figure 3. TEM images of different $\mathrm{LDH}-\mathrm{NO}_{3}$ and $\mathrm{LDH}-\mathrm{POM}$ samples

According to the TEM images from Figure 3. $\mathrm{Mg}_{2} \mathrm{AlNi}-\mathrm{POM}$ $\mathrm{LDH}$ and $\mathrm{Mg}_{3} \mathrm{Al}-\mathrm{POM} \mathrm{LDH}$ keep the plate morphology for $\mathrm{LDH}$ host. Compared with $\mathrm{Mg}_{2} \mathrm{AlNi}-\mathrm{NO}_{3} \mathrm{LDH}$ and $\mathrm{Mg}_{2} \mathrm{AlNi}-\mathrm{NO}_{3} \mathrm{LDH}$, LDH host of $\mathrm{Mg}_{3} \mathrm{Al}-\mathrm{POM} \mathrm{LDH}$ is not clearly observed because of the partial decomposition of LDH host in the anion-exchange process..$^{23}$ Furthermore, the layer of $\mathrm{Mg}_{2} \mathrm{AlNi}-\mathrm{POM} \mathrm{LDH}$ is more complete than $\mathrm{Mg}_{3} \mathrm{Al}-\mathrm{POM} \mathrm{LDH}$ which maybe due to the addition of nickel species reducing the alkalinity of LDH hosts to effectively restrain the decomposition of LDH host.

The thermal stability of samples were studied using TGA and the obtained results have been shown in Figure 4. The values of the major losses produced during LDH decomposition are shown in Table 1. The first weight loss (peak 1) is broader and appearing clearly at temperatures below $200{ }^{\circ} \mathrm{C}$, which could be attributed to the loss of non-structural water physisorbed on the external surface of the
LDH crystallites. From 200 to $500{ }^{\circ} \mathrm{C}$ (peak 2), the observed weight losses could be associated to water differently bonded to the structure such as interlayer water co-intercalated with nitrate or chemisorbed water. ${ }^{34}$ Ternary $\mathrm{Mg}_{2} \mathrm{AlNi}-\mathrm{POM} \mathrm{LDH}$ and $\mathrm{Mg}_{2} \mathrm{AlNi}-\mathrm{NO}_{3} \mathrm{LDH}$ are more stable than binary $\mathrm{Mg}_{3} \mathrm{Al}-\mathrm{POM} \mathrm{LDH}$ and $\mathrm{Mg}_{2} \mathrm{AlNi}-\mathrm{NO}_{3} \mathrm{LDH}$.

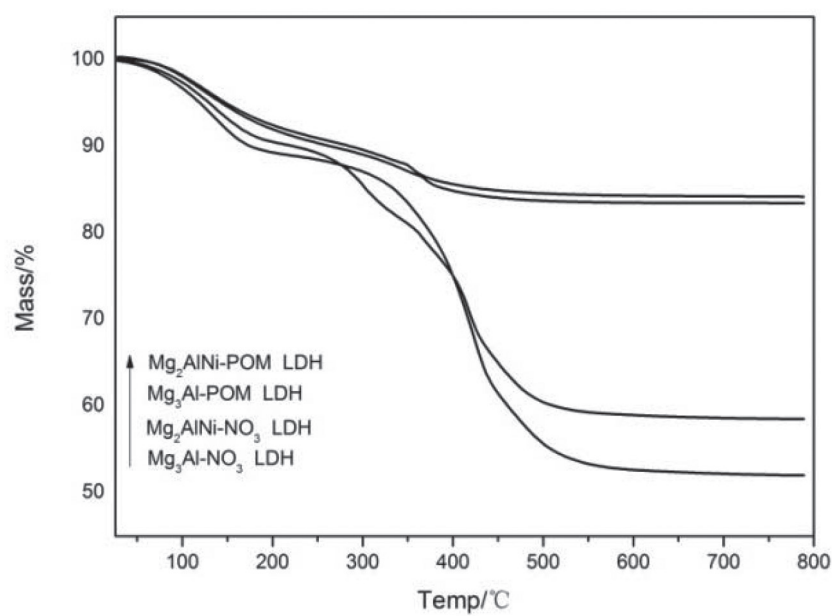

Figure 4. TGA traces for the representative $\mathrm{LDH}-\mathrm{NO}_{3}$ and $\mathrm{LDH}-\mathrm{POM}$ samples

\section{Catalytic performance of $\mathrm{Mg}_{2} \mathrm{AINi}-\mathrm{POM} \mathrm{LDH}$ in the oxidation of cyclohexanol}

Catalytic performance between $\mathrm{Mg}_{2} \mathrm{AlNi}-\mathrm{POM} \mathrm{LDH}$ and $\mathrm{Mg}_{3} \mathrm{Al}-$ POM LDH is different for the oxidation of cyclohexanol (Table 1). Although POM has good catalytic performance, it is a homogeneous catalysis. $\mathrm{Mg}_{2} \mathrm{AlNi}-\mathrm{POM} \mathrm{LDH}$ exhibits higher conversion and selectivity to cyclohexanone (the catalytic activity of $\mathrm{Mg}_{2} \mathrm{AlNi}-\mathrm{POM}$ $\mathrm{LDH}$ was evaluated in triplicates and the error bars have been shown in Figure 5) than $\mathrm{Mg}_{3} \mathrm{Al}-\mathrm{POM} \mathrm{LDH}$, which is due to the synergistic effect of nickel. This is further proved through the results as shown in Table 2 which indicates the comparison between catalysts with different molar ratio of $\mathrm{Ni}$ in the preparation of cyclohexanone by the oxidation of cyclohexanol. We could clearly conclude that the conversion and selectivity to cyclohexanone increase with an increase in the molar ratio of $\mathrm{Ni}$ of POM-LDH.

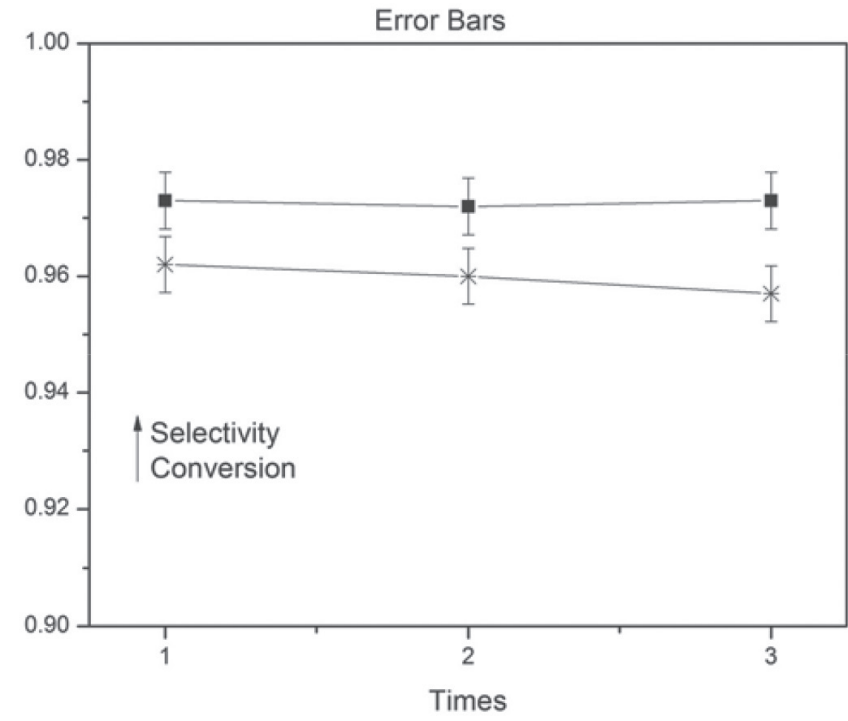

Figure 5. Error bars on selectivity and conversion of $\mathrm{Mg}_{2} \mathrm{AlNi}-\mathrm{POM} \mathrm{LDH}$ catalysts 
Table 1. Comparison between different Catalysts in preparation of cyclohexanone by oxidation of cyclohexanol and values of the $\mathrm{d}(003)$ spacing<smiles>O=C1CCCCC1CCCOCCO</smiles>

\begin{tabular}{lcccc}
\hline Entry & Catalyst & $\begin{array}{c}\text { Conversion } \\
(\%)\end{array}$ & $\begin{array}{c}\text { Selectivity } \\
(\%)\end{array}$ & $\mathrm{d}(003) / \mathrm{nm}$ \\
\hline 1 & $\mathrm{Mg}_{3} \mathrm{Al}-\mathrm{POM} \mathrm{LDH}$ & 82 & 43 & 1.46 \\
2 & $\mathrm{Mg}_{2} \mathrm{AlNi}-\mathrm{POM} \mathrm{LDH}$ & 95 & 97 & 1.49 \\
3 & $\mathrm{Mg}_{3} \mathrm{Al}-\mathrm{NO}_{3} \mathrm{LDH}$ & - & - & 0.82 \\
4 & $\mathrm{Mg}_{2} \mathrm{AlNi}-\mathrm{NO} 3 \mathrm{LDH}$ & - & - & 0.89 \\
5 & $\mathrm{POM}$ & 99.5 & 100 & - \\
\hline
\end{tabular}

Table 2. Comparison between Catalysts with different molar rations of $\mathrm{Ni}$ in preparation of cyclohexanone by oxidation of cyclohexanol

\begin{tabular}{lcccc}
\hline Entry & Catalyst & $\begin{array}{c}\text { The molar } \\
\text { ration of } \\
\mathrm{Mg} / \mathrm{Al} / \mathrm{Ni}\end{array}$ & $\begin{array}{c}\text { Conversion } \\
(\%)\end{array}$ & $\begin{array}{c}\text { Selectivity } \\
(\%)\end{array}$ \\
\hline 1 & $\mathrm{Mg}_{2.5} \mathrm{AlNi}_{0.5}-\mathrm{POM} \mathrm{LDH}$ & $2.5 / 1.0 / 0.5$ & 95 & 96 \\
2 & $\mathrm{Mg}_{2} \mathrm{AlNi}_{-} \mathrm{POM} \mathrm{LDH}$ & $2.0 / 1.0 / 1.0$ & 95 & 97 \\
3 & $\mathrm{Mg}_{1.5} \mathrm{AlNi}_{1.5}-\mathrm{POM} \mathrm{LDH}$ & $1.5 / 1.0 / 1.5$ & 96 & 97 \\
4 & $\mathrm{MgAlNi}_{2}-\mathrm{POM} \mathrm{LDH}$ & $1.0 / 1.0 / 2.0$ & 97 & 98 \\
5 & $\mathrm{Mg}_{0.5} \mathrm{AlNi}_{2.5}-\mathrm{POM} \mathrm{LDH}$ & $0.5 / 1.0 / 2.5$ & 98 & 99 \\
\hline
\end{tabular}

In addition, the decomposition of hydrogen peroxide can also affect the catalytic performance. When $\mathrm{pH}$ is less than 3.5 , hydrogen peroxide maintains the stability. ${ }^{35}$ The measured $\mathrm{pH}$ of the catalytic environment of $\mathrm{Mg}_{3} \mathrm{Al}-\mathrm{POM} \mathrm{LDH}$ and $\mathrm{Mg}_{2} \mathrm{AlNi}-\mathrm{POM} \mathrm{LDH}$ were 4.7 and 4.3, respectively. It exhibits that the addition of nickel could reduce the alkalinity of the material itself and reduces the rate of decomposition of hydrogen peroxide.

\section{Stability and recyclability of LDH-POM catalysts}

The LDH-POM catalysts could be reused with negligible loss of catalytic activity after five runs (Figure 6). The cyclohexanone's selectivity retained over $95 \%$ even after its usage for five times. However, the activity of $\mathrm{Mg}_{3} \mathrm{Al}-\mathrm{POM} \mathrm{LDH}$ catalyst is decreased after the first reuse, suggesting that the $\mathrm{Mg}_{3} \mathrm{Al}-\mathrm{POM} \mathrm{LDH}$ is unstable towards the oxidation of cyclohexanol. These results demonstrate that $\mathrm{Mg}_{2} \mathrm{AlNi}-\mathrm{POM} \mathrm{LDH}$ is a stable heterogeneous catalysis in the aqueous oxidation. The recovered $\mathrm{Mg}_{2} \mathrm{AlNi}-\mathrm{POM} \mathrm{LDH}$ catalyst after the fifth cycle was characterized again by XRD (Figure 7) and FT-IR (Figure 8) to evaluate the structural stability. Compared to the fresh catalyst, no significant changes were observed in the XRD and IR spectra. These observations provide direct evidence that the $\mathrm{Mg}_{2} \mathrm{AlNi}$ POM LDH catalyst is stable under the subjected reaction conditions.

\section{CONCLUSIONS}

In summary, we have fabricated ternary catalysts through ionexchange method without adjusting the $\mathrm{pH}$. The followed steps for the intercalation of POM anion into LDH is convenient, environmentally benign and more importantly cheaper. Besides, it provides an efficient heterogeneous oxidation catalysis. Furthermore, we have examined the catalytic performance of $\mathrm{Mg}_{2} \mathrm{AlNi}-\mathrm{POM} \mathrm{LDH}$ in the oxidation of cyclohexanol as compared with the conventional catalyst, $\mathrm{Mg}_{3} \mathrm{Al}-$ $\mathrm{POM} \mathrm{LDH}$. The resulting heterogeneous catalysis $\mathrm{Mg}_{2} \mathrm{AlNi}-\mathrm{POM}$
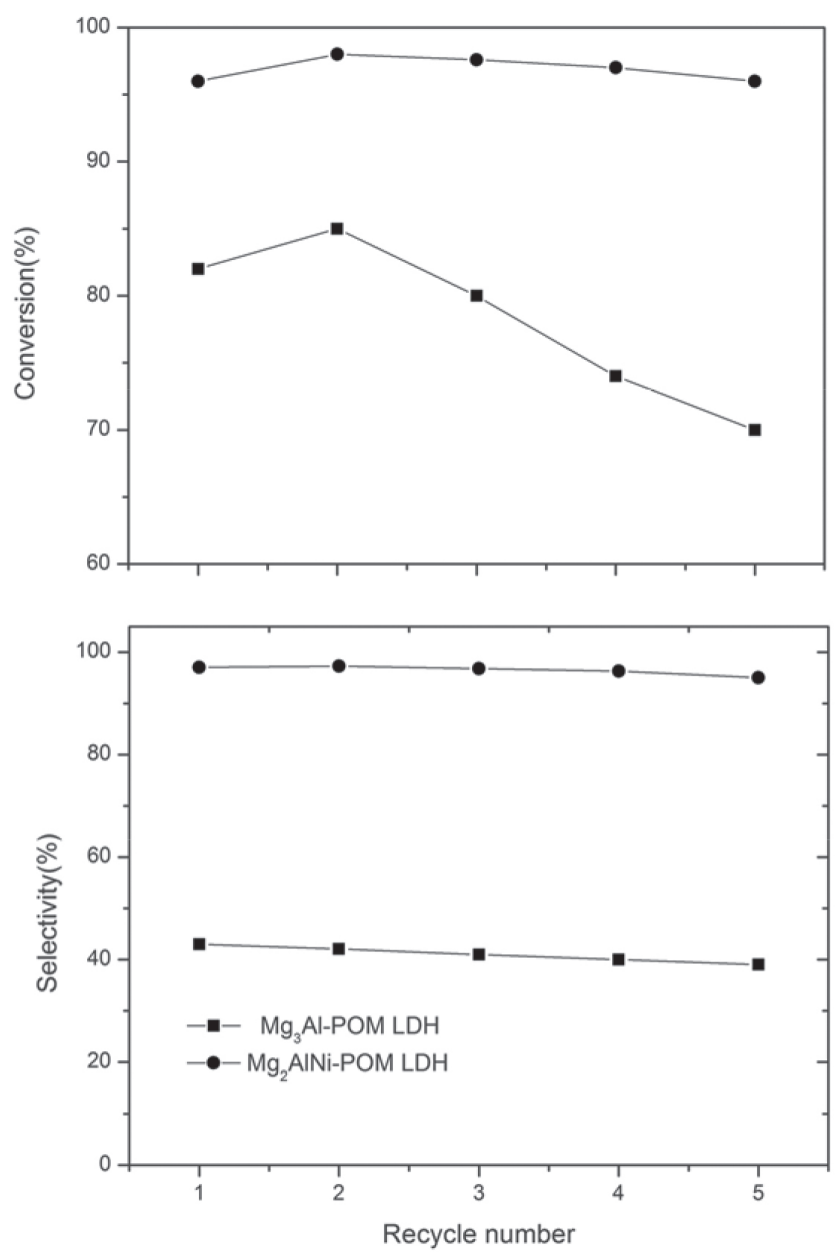

Figure 6. Recyclability of $\mathrm{Mg}_{3} \mathrm{Al}-\mathrm{POM} \mathrm{LDH}$ and $\mathrm{Mg}_{2} \mathrm{AlNi}-\mathrm{POM} \mathrm{LDH}$ catalysts

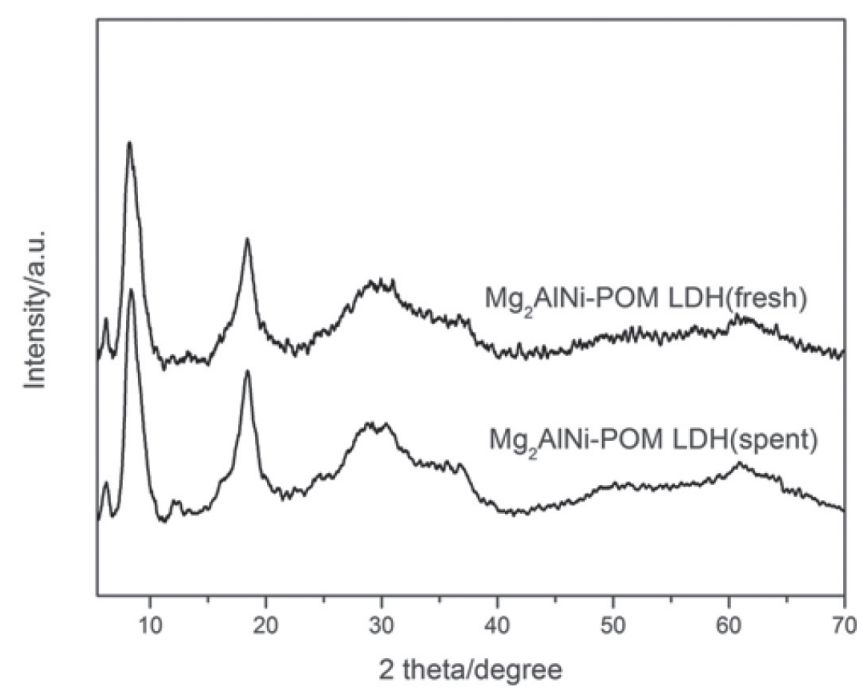

Figure 7. XRD patterns of fresh $\mathrm{Mg}_{2} \mathrm{AlNi}-\mathrm{POM} \mathrm{LDH}$ and spent $M g_{2} \mathrm{AlNi}-\mathrm{POM}$ $L D H$

LDH showed a much higher catalytic performance than the corresponding catalyst i.e. $\mathrm{Mg}_{3} \mathrm{Al}-\mathrm{POM} \mathrm{LDH}$. This is mainly due to the synergetic effects between nickel and POMs. The original crystal structure of $\mathrm{Mg}_{2} \mathrm{AlNi}-\mathrm{POM} \mathrm{LDH}$ was maintained. Additionally, the $\mathrm{Mg}_{2} \mathrm{AlNi}-\mathrm{NO}_{3} \mathrm{LDH}$ precursor with lower surface basicity is more effective than the $\mathrm{Mg}_{3} \mathrm{Al}-\mathrm{NO}_{3} \mathrm{LDH}$, keeping the stability of 


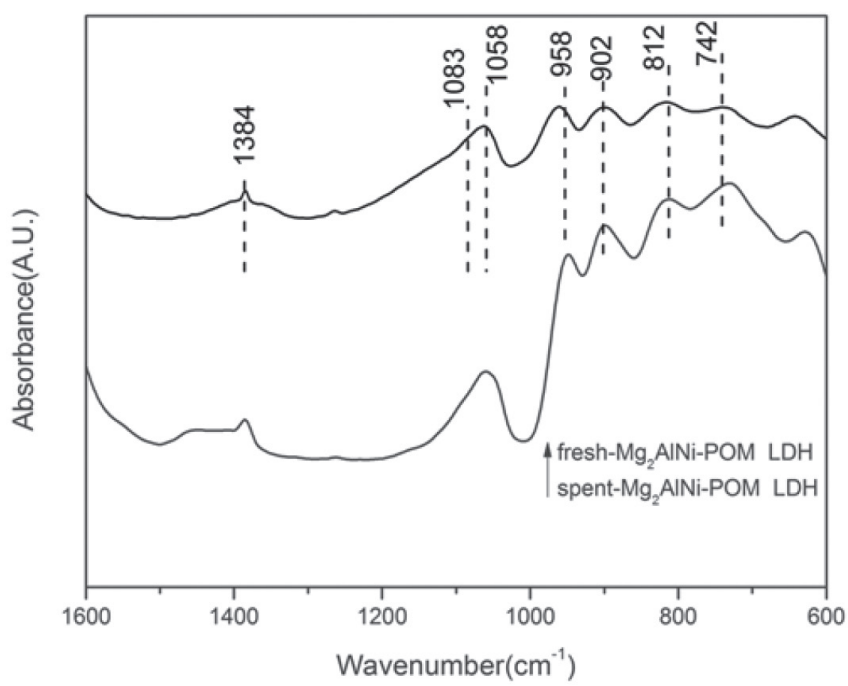

Figure 8. FT-IR spectra of fresh $\mathrm{Mg}_{2} \mathrm{AlNi}-\mathrm{POM} \mathrm{LDH}$ and spent $\mathrm{Mg}_{2} \mathrm{AlNi}-\mathrm{POM}$ $L D H$

the material and reducing the hydrolysis of aqueous $\mathrm{H}_{2} \mathrm{O}_{2}$. Overall, this work offers a green chemistry strategy for the improvement of heterogeneous oxidation using aqueous $\mathrm{H}_{2} \mathrm{O}_{2}$.

\section{ACKNOWLEDGMENTS}

This work was supported by the National Natural Science Foundation. (NO. 20573071)

\section{REFERENCES}

1. Pybus, D. H. In The chemistry of fragrances; Pybus, D. H.; Sell, C. S., eds.; Royal Society of Chemistry: London, 2006.

2. Singh, R. P.; Subbarao, H. N.; Dev, S.; Tetrahedron 1979, 35, 1789.

3. Fey, T.; Fischer, H.; Bachmann, S.; J. Org. Chem. 2001, 66, 8154.

4. Ishii, Y.; Yamawaki, K.; Ura, T.; J. Org. Chem. 1989, 20, 3587.

5. Noyori, R.; Aoki, M.; Sato, K.; Chem. Commun. 2003, 34, 1977.
6. Kortz, U.; Müller, A.; Slageren, J. V.; Coord. Chem. Rev. 2009, 253, 2315.

7. Keita, B.; Liu, T.; Nadjo, L.; ChemInform 2009, 40, 19.

8. Bi, L. H.; Hou, G. F.; Li, B.; Wu, L. X.; Kortz, U.; Dalton Trans. 2009, 32, 6345 .

9. Long, D. L.; Tsunashima, R.; Cronin, L.; Angew. Chem., Int. Ed. 2010, 49,1736.

10. Grigoropoulou, G.; Clark, J. H.; Elings, J. A.; Green Chem. 2003, 5, 1.

11. Lane, B. S.; Burgess, K.; Chem. Rev. 2003, 103, 2457.

12. Mizuno, N.; Yamaguchi, K.; Kamata, K.; J. Coord. Chem. Rev. 2005, 249, 1944.

13. Mizuno, N.; Kamata, K.; Yamaguchi, K.; Top. Catal. 2010, 53, 876.

14. Lv, H.; Geletii, Y. V.; Zhao, C.; Chem. Soc. Rev. 2012, 41, 7572.

15. Guo, Y.; Li, D.; Hu, C.; Microporous Mesoporous Mater. 2002, 56, 153.

16. Guo, Y.; Li, D.; Hu, C.; Int. J. Inorg. Mater. 2001, 3, 347.

17. Guo, Y.; Li, D.; Hu, C.; Appl. Catal., B 2001, 30, 337.

18. Pinnavaia, T. J.; Kwon, T.; Dimotakis, E. D.; US pat. 5079203, 1992.

19. Nijs, H.; Bock, M. D.; Maes, N.; Porous Mater. 1999, 6, 307.

20. Hasannia, S.; Yadollahi, B.; Polyhedron 2015, 99, 260.

21. Wei, X.; Fu, Y.; Xu, L.; J. Solid State Chem. 2008, 181,1292.

22. Franklin, I. L.; Ph. D. Thesis, University of London, London 2005.

23. Liu, P.; Wang, C.; Li, C.; J. Catal. 2009, 262, 159.

24. Guo, J.; Sun, T.; Shen, J.; Acta Sci. Nat. Univ. Jilin. 1995, 16, 346.

25. Arco, M. D.; Carriazo, D.; Gutiérrez, S.; Inorg. Chem. 2004, 43, 375.

26. Sousa, F. L.; Ferreira, A. S.; Ferreira, R. A. S.; ChemInform 2006, 37, 726

27. Jana, S. K.; Kubota, Y.; Tatsumi, T.; J. Catal. 2008, 255, 40.

28. Choudary, B. M.; Kantam, M. L.; Rahman, A.; Angew. Chem., Int. Ed. 2001, 40, 763.

29. Choudhary, V. R.; Chaudhari, P. A.; Narkhede, V. S.; Catal. Commun. 2003, 4, 171.

30. Velusamy, S.; Punniyamurthy, T.; Org. Lett. 2004, 6, 217.

31. Meng, X.; Lin, K.; Yang, X.; J. Catal. 2003, 218, 460.

32. Meng, X. J.; Xiao, F. S.; Acta Phys.-Chim. Sin. 2004, 20, 939.

33. Liu, Y.; Murata, K.; Hanaoka, T.; J. Catal. 2007, 248, 277.

34. Guil-López, R.; Navarro, R. M.; Peña, M. A.; Int. J. Hydrogen Energy. 2011, 36, 1512 .

35. Zhang, Q.; Ying, C. Y.; Ke-Na, Y. U.; Journal of Jiaxing University 2010. 